\title{
STUDENT JAKO WYTWÓRCA: INSTYTUCJA DOBRA WSPÓLNEGO? CZYLI O TYM, JAK ODZYSKAĆ KOMUNISTYCZNĄ/REWOLUCYJNĄ NAUKĘ
}

\author{
MIKE NEARY
}

PRZEŁoŻYŁa: JoANNA BEDNAREK

\begin{abstract}
Abstrakt: Niniejszy artykuł stanowi próbę rozwinięcia pojęcia studenta jako wytwórcy, stanowiącą część projektu, którego celem jest radykalizacja idei uniwersytetu przez powiązanie badań i dydaktyki z wizją szkolnictwa wyższego i rewolucyjnej nauki opartych na powtórnym powiązaniu nauk przyrodniczych i społecznych. Argumentacja rozwijana jest za pomoca krytycznej dyskusji z klasycznymi pracami z zakresu teorii zarządzania, jak również z tekstami marksistowskimi, które pojawiły się dzięki niedawnej fali studenckich protestów przeciwko postępującej prywatyzacji i finansjeryzacji szkolnictwa wyższego. Artykuł przedstawia studium przypadku, w którym nauki przyrodnicze i społeczne zostały połączone w ramach programu studiów drugiego stopnia, „edukacji badawczej”, prowadzonego na Uniwersytecie w Lincoln, w Wielkiej Brytanii. Obejmuje on dyskusję na temat istoty rewolucyjnej nauki, prowadzona poprzez omówienie prac dwóch głównych naukowców-rewolucjonistów, Roberta Grosseteste'a (1175-1253) i Karola Marksa (1818-1883).
\end{abstract}

Słowa kluczowe: biurokracja, dobro wspólne, nauki przyrodnicze i społeczne, rewolucja, uniwersytet 
$Z$ niczego nic nie uzyskas\%:

Shakespeare, Król Lear, akt I, scena I

Znamy tylko jedna jedyna nauke. Marks i Engels, Ideologia niemiecka $(1961,18)$

Jeśli chcemy, by wszystko pozostało tak, jak, jest, wszystko sie musi zmienić. Lampedusa, Lampart $(1961,48)$

...na poznaniu meteorón opiera się sžczéśliwość. Marks, Rozprawa doktorska (1966, 93)

\section{Coś więcej niż „studenckie zaangażowanie”}

Projekt Student jako wytwórca jest często klasyfikowany jako dotyczący „studenckiego zaangażowania" (Taylor i Wilding 2009; OAA 2012a). Podstawą idei studenckiego zaangażowania w szkolnictwie wyższym jest szukanie sposobów na wykorzystanie inteligencji studentów w procesie doskonalenia nauki i nauczania (Hagyard 2009) oraz włączanie studentów w prace badawcze prowadzone przez uniwersytet poprzez zachęcanie ich do współpracy $\mathrm{z}$ badaczami i branie udziału w wartościowych intelektualnie projektach badawczych (Bovill, Cook-Sather i Felten 2011). Projekt Student jako wytwórca rzeczywiście dotyczy wszystkich tych zagadnień, jak również wielu innych. Tym jednak, co czyni go czymś więcej niż zwykłą interpretacją studenckiego zaangażowania, jest fakt, że jego stawką jest sama przyszłość uniwersytetu (Neary i Winn 2009).

W ramach obowiązującego obecnie ujęcia „studenckiego zaangażowania”, w którym studentów uznaje się za ,serce systemu” (Browne 2010), nie kwestionuje się samego uniwersytetu jako formy instytucjonalnej. Zaangażowanie ma się pojawiać w obrębie istniejących, quasi-korporacyjnych struktur zarządzania szkolnictwa wyższego (Lambert i in. 2012). Jednak dla projektu Student jako wytwórca głównym celem jest wynalezienie na nowo instytucjonalnej postaci szkolnictwa wyższego (Boyer 1990): zamiast być postmodernistycznym „nie-miejscem” (Auge 2013), w którym studenci odgrywają rolę hiperkonsumpcyjnych „czynników zmiany” (Zandstra i Dunne 2009), nasz radykalny projekt polityczny i socjologiczny (Fuller 2009) dąży do przywołania z powrotem uniwersytetu takiego, jakim był u swoich średniowiecznych początków - jako przestrzeni praktycznej, eksperymentalnej nauki (Southern 1992), przeciwstawiając się „akademickiemu kapitalizmowi”, na którym opiera się współczesny neoliberalny uniwersytet (Slaughter i Rhoades 2004). Student jako wytwórca chce 
odzyskać postępową wizję XIX-wiecznych idealistów niemieckich, w myśl której uniwersytet ma być przestrzenia dla filozofii spekulatywnej, czyli swego rodzaju społeczną encyklopedią wiedzy (Lyotard 1997). Projekt zakorzenia ten ,ideał uniwersytetu” w radykalnych wystapieniach studencko-robotniczych z 1968 roku i nowych formach protestu studenckiego z początku XXI wieku, zwróconych przeciwko prywatyzacji życia akademickiego, sprzedawanego pod postacią „przeżycia studenckiego”, podporządkowanego głównemu celowi, jakim ma być przyszła możliwość zatrudnienia (HEFCE 2010). W Wielkiej Brytanii prywatyzację tę nasiliła decyzja rządu, by zmniejszyć finansowanie kierunków artystycznych, humanistycznych i społecznych, pozbawiając dostępu do publicznych pieniędzy dziedziny, w których kultywuje się tradycje krytycznych teorii społecznych. To nic innego, jak reakcyjne posunięcie polityczne, intelektualny wandalizm i wypowiedzenie wojny krytyce.

Nie jest celem projektu podtrzymywanie społecznej fikcji, jaką stanowią walki wokół fałszywej dychotomii publicznych i prywatnych funkcji szkolnictwa wyższego; obie są przecież dopełniającymi się wzajemnie formami kapitalistycznej regulacji (Neary 2012a). Jego celem jest natomiast „rozpuszczenie” (Holloway 2010), albo, jeszcze lepiej, „doprowadzenie do eksplozji” (Lefebvre 1991) kapitalistycznego stosunku społecznego, z którego wywodzi się współczesna postać uniwersytetu (Neary 2012a), tak, by stworzyć uniwersytet jako nową formą instytucji społecznej, coś, co Gigi Roggero określa mianem „instytucji dobra wspólnego” (Roggero 2011).

W przeciagu kilku ostatnich lat idea dobra wspólnego zaczęła cieszyć się sporym zainteresowaniem w postępowych kręgach akademickich, stanowiąc sposób na powrót do akademickich wartości otwartości i dzielenia się wiedzą. W jednej z najważniejszych wypowiedzi w ramach tej debaty Roggero wprowadza rozróżnienie między pojęciem „dóbr wspólnych” (the commons) jako zasobu pochodzącego ze świata przyrodniczego, a pojęciem „dobra wspólnego” (the common) jako czegoś społecznie skonstruowanego. Ta pozornie prosta dychotomia - „dobro wspólne” przeciwstawione „dobrom wspólnym” - jest ważna, ponieważ wskazuje na pewne przemilczenie w nauce marksistowskiej, dotyczące związku między wymiarem ludzko-społecznym i wymiarem przyrodniczo-materialnym. XX-wieczny marksizm skupiał się na wymiarze ludzko-społecznym kosztem tego, co przyrodnicze, czyniąc siebie podatnym na zarzut, że Marks ma niewiele do powiedzenia o biopolityce czy té̇ polityce ekologicznej, a nawet, że marksistowska nauka dokonuje desakralizacji natury za sprawą władczego, „prometejskiego” podejścia do niej (Foster 2000).

Ten brak powiązania między światem przyrodniczym i społecznym doprowadził do oddzielenia nauk przyrodniczych i społecznych, co ma poważne konsekwencje dla każdego projektu mającego na celu wynalezienie na nowo szkolnictwa wyższego. Radykalne, krytyczne bądź utopijne projekty edukacyjne tworzone w Europie Zachodniej koncentrowały się raczej na wymiarze społeczno-ludzkim niż przyrodniczym (Cote, Day i de Peuter 2007). Krytyczna 
inspiracja pracami Roggero pozwala jednak projektowi Student jako wytwórca na dalszą radykalizację, wykroczenie poza filozofię edukacji czy rewolucyjną politykę pedagogiki krytycznej i powszechnej edukacji, skupiającej się na politycznym wymiarze relacji nauczycieluczeń i na humanizacji wiedzy. Problematyczne rozróżnienie między „dobrami wspólnymi” i „dobrem wspólnym” domaga się od naszego projektu zmierzenia się z wzajemnym stosunkiem nauk przyrodniczych i ścisłych, uznając za pilny problem sam praktyczny związek nauk przyrodniczych i społecznych, a także powiązanie ludzkości ze światem przyrodniczym tak, by powstała jedna nauka: komunizm, pozwalający uniknąć ekologicznej katastrofy. Przekształcenie relacji między naukami przyrodniczymi i społecznymi będzie miało poważny wpływ na sposób, w jaki uniwersytet działa i w jaki jest ustrukturyzowany.

Komunistyczna nauka nie rości sobie prawa do obiektywizmu: naukowiec zajmuje zgodnie $\mathrm{z}$ nią stanowisko polityczne, zakorzenione $\mathrm{w}$ historii $\mathrm{i}$ tradycji doświadczeń ugruntowanych w obiektywnej i subiektywnej walce o byt. Zgodnie ze stanowiskiem nauki komunistycznej umiejscowienie polityczne nie jest postrzegane jako coś posiadającego szkodliwy wpływ na pracę badawcza, ale raczej stanowi podstawową rzeczywistość obiektywna, z której wyprowadzana jest praktyczna wiedza krytyczna. Posługując się słownikiem burżuazyjnej metody badawczej, w niniejszym artykule pozostaję, jako głos autorski, usytuowany między wieloma określonymi formalnie tożsamościami. Występuje jednocześnie jako: aktywista uniwersytecki, Dziekan do spraw Dydaktyki na Uniwersytecie w Lincoln i scolaire provocateur związany z projektem Student jako wytwórca; nie wspominając o innych aspektach mojej biografii, które mógłbym również tu ująć byciu ojcem, mężem, bratem, przyjacielem i wrogiem. W słowniku niefunkcjonalnej nauki rewolucyjnej za moje usytuowanie odpowiada, jak zobaczymy, „siła abstrakcji” (Marks 1968, 6), przez która rozumiem za Marksem, znaczący proces, w którym tworzy się moja podmiotowość polityczna. Dla Marksa abstrakcja jest procesem konkretnym, nie mentalnym, zakładającym nie tylko „ślepy przymus stosunków ekonomicznych” (Marks 1968, 876), za sprawą którego z procesu pracy wypompowywana jest wartość dodatkowa, a moja kondycja pracownika dla kapitału jest potwierdzana jako „abstrakcja rzeczywista”, ale (co dla moich celów ważniejsze) również opór wobec tego tępego przymusu i mojego statusu najemnej siły roboczej oraz pojawiającą się dzięki temu oporowi możliwość radykalnie alternatywnego świata, w którym moje potrzeby i zdolności jako jednostki społecznej byłyby raczej zasadami działania, nie zaś zasobami podlegającymi rabunkowi.

\section{Coś innego niż zarządzanie zmianą}

Student jako wytwórca ma na celu zaprowadzenie zmian instytucjonalnych, dlatego może być postrzegany jako projekt $\mathrm{z}$ dziedziny zarządzania zmianą, w którym studenci pełnią funkcję 
„,czynników zmiany” (Zandstra i Dunne 2009). Zarządzanie zmianą to najświeższa moda w teorii zarządzania i badaniach nad organizacją (Birnbaum 2000). Opiera się ona na fantazji, że tylko organizacje, które stają się coraz bardziej przedsiębiorcze i innowacyjne, będą mogły przetrwać w nowej rzeczywistości gospodarczej (Peters 1992). W ostatnim okresie rzeczywistość tę określają środki oszczędnościowe i niepewność, sprawiając, że pragnienia zmiany staje się coraz pilniejsze i bardziej konieczne (Du Gay 2000, 63-64). Dzięki temu zarządzanie zmianą może przeciwstawić się biurokracji, która w literaturze tego nurtu pojawia się pod postacią regulacji, opóźniania, niezdecydowania, rozbudowanej administracji, państwa opiekuńczego i tendencji do nieudolności (Du Gay 2000).

Wymowny przykład tego pędu ku zarządzaniu zmianą można znaleźć w pochodzącej od Petera Druckera wizji „postkapitalistycznego” świata organizacji; definiuje on postkapitalizm jako „społeczeństwo wiedzy” i określa „pracownika intelektualnego” jako postać w tym społeczeństwie wzorcowa (Drucker 1993). Jak to ujmuje:

Rzeczywistym, kluczowym zasobem i decydującym „czynnikiem produkcji” nie jest dziś ani kapitał, ani ziemia czy praca. Jest nim wiedza. W społeczeństwie postkapitalistycznym mamy do czynienia już nie z kapitalistami i proletariatem, ale z klasa pracowników intelektualnych i pracowników usługowych (Drucker 1993, 6).

W nowym wspaniałym postkapitalistycznym świecie Druckera społeczną władzę sprawują osoby wykształcone, dzielące się na intelektualistów i menedżerów. Pierwsi żyją w świecie idei, drudzy w świecie pracy; nie mogą oni istnieć bez siebie nawzajem, ponieważ innowacyjną produktywność osiaga się, przekształcając wiedzę w użyteczne produkty (Drucker 1993).

Drucker nie sądził, by uniwersytet zachował swoją obecną formę instytucjonalną; postrzegał go jako relikt społeczeństwa kapitalistycznego, przytłoczony konsumpcyjnymi wymogami postkapitalizmu i przemysłów wiedzy (Rhodes 2001, xii). Jak przewiduje:

\footnotetext{
Za trzydzieści lat wielkie kampusy uniwersyteckie staną się przeżytkami. Uniwersytety nie przetrwają. To przełom podobny temu, gdy po raz pierwszy wydrukowano książkę. Szkolnictwo wyższe jest w głębokim kryzysie (Forbes www.forbes.com/forbes/ 1997/0310/5905122a 7.html).
}

Projekt Student jako wytwórca przeciwstawia się zdecydowanie Druckerowskiemu światu postkapitalistycznemu i idei fabryki wiedzy, na której się on wspiera. Podobnie jak Drucker, wychodzę od pojęcia społeczeństwa postkapitalistycznego, różnię się jednak od niego pod dwoma ważnymi względami, uważam bowiem, że: po pierwsze, akademickie wartości i etyka poprzedzają i przeciwstawiają się urynkowieniu wymuszanemu przez gospodarkę opartą na wiedzy; po drugie, społeczeństwo postkapitalistyczne trzeba dopiero stworzyć. 


\section{Wartość biurokracji}

Przywiązanie do wartości i etyki akademickiej oraz niechęć do projektu narzucania logiki korporacyjnej można wesprzeć rewaluacja biurokracji rozumianej jako zestaw procedur i procesów zakorzenionych w wysoce cenionych w naszym społeczeństwie obyczajach i etyce. Wartości te obejmuja demokrację, sprawiedliwość, równość, wolność i wspólpracę. Zgodnie z tą definicja, podążająca za Maksem Weberem (2002), biurokracja to „obszar znaczacej dziedziny etycznej" (Du Gay 2000, 2) a także

\footnotetext{
szczególny etos $(\ldots)$ obejmujący nie tylko cele i ideały wchodzące w skład pewnego kodeksu postępowania, ale także sposoby działania (...) biuro trzeba oceniać samo w sobie, jako szczególną instytucję etyczna; etyczne cechy biurokraty trzeba postrzegać jako przygodne i często kruche zdobycze jest społecznie organizowanej sfery egzystencji moralnej (Du Gay 2000, 4).
}

Środowisko biurokratyczne posiada zatem właściwą sobie racjonalność i celowość (Du Gay $2000,75)$.

Do tej próby opisania na nowo biurokracji jako kierującej się racjonalnymi i etycznymi zasadami można dodać jasny zamiar zbiorowej, demokratycznej dekonstrukcji roli prorektorów jako charyzmatycznych przywódców, od których wizji, jak się wydaje, zależy przyszły dobrobyt i reputacja uniwersytetu jako przedsiębiorstwa (Goodall 2009).

\section{Wartość wartości}

W odróżnieniu od tez Druckera, Student jako wytwórca opiera się na tezie, że postkapitalizm jeszcze nie zaistniał. Cechą wyróżniająca kapitalizmu jest dla tego projektu nie rodzaj wytwarzanych towarów, ale fakt organizacji społeczeństwa zgodnie z formą towarową. Dlatego tak długo, jak forma towarowa stanowi zasadę organizacyjną społeczeństwa, jest dosłownie bez znaczenia, jakie towary się produkuje (Marks 1968). Forma towarowa wskazuje na fakt, że podstawową zasadą organizacyjną społeczeństwa kapitalistycznego jest nie wymiana handlowa, ale produkcja, będąca miejscem, w którym wytwarzana jest wartość (Clarke 1991).

Przejście do społeczeństwa postkapitalistycznego może się dokonać, w myśl założeń projektu, nie za sprawą dostosowania się do istniejącego stanu rzeczy, ale dzięki stworzeniu nowych warunków, wywiedzionych z procesu przekształcania tych, które istnieją teraz. Konieczność tego przekształcania wynika z faktu, że ani system rozwoju społecznego kierowany przez rynek, ani model stałego wzrostu, na którym się on opiera, nie mogą istnieć dalej: oba prowadzą do katastrofalnych, przekraczających ludzką wyobraźnię konsekwencji. Główna różnica między postkapitalistycznym światem Druckera i światem naszego projektu 
polega na tym, że w myśl tego drugiego podmioty społeczne nie dostosowują się po prostu do nowej sytuacji obiektywnej, ale obiektywne warunki nowego porządku społecznego sa przekształcane przez działania podmiotów społecznych. Jak wskazuje tytuł Student jako wytwórca, przekształcenia te mają zachodzić głównie w dziedzinie produkcji, nie zaś wymiany, i dokonywać się za sprawą rożnych form organizacji wspólnotowości, wyłaniających z siebie różne formy możliwego zawłaszczania wytworów pracy. Gdyby oprzeć przekształcenie wyłącznie na logice wymiany, jak dzieje się to w tak zwanym postkapitalistycznym świecie Druckera, jedyną konsekwencją projektu byłoby upewnienie się, że nic się nie zmieni, że świat pozostanie taki sam: „Jeśli chcemy, by wszystko pozostało tak, jak jest, wszystko się musi zmienić" (Lampedusa 1961, 48). W społeczeństwie postkapitalistycznym, na rzecz którego działa projekt Student jako wytwórca, produktów dowolnego rodzaju nie wytwarza się w celu wymiany, ale po to, by odpowiadały na potrzeby i możliwości świata społecznego, w którym są wytwarzane, zgodnie z komunistyczną logiką „Każdy według swych zdolności, każdemu według jego potrzeb!” (Marks 1972, 24). Owa komunistyczna logika stanowi podstawę tego, co Roggero (2011) nazywa ,instytucją dobra wspólnego”.

\section{Kryzys: co robią radykalni intelektualiści?}

Drucker miał rację co do jednego: szkolnictwo wyższe znajduje się w kryzysie.

Projekt Student jako wytwórca wyłonił się z kryzysu, czy też, dokładniej, z „podwójnego kryzysu” (Edu-factory 2009). Kryzys dotyczy, po pierwsze, znaczenia i celu edukacji wyższej, w obrębie której można zaobserwować tendencję do coraz większego skupienia na urynkowieniu i komercjalizacji oraz umieszczania studenta w roli konsumenta. Po drugie zaś mamy do czynienia z głębszym kryzysem, którego pochodną jest kryzys znaczenia i celu kryzysem wywołanym przez trwające nadal załamanie modelu rozwoju społecznego stawiającego rynek na pierwszym miejscu, którego dowodem jest niedawna Wielka Recesja (McNally 2011) i kres neoliberalnego projektu rozumianego jako zestaw praktyk i zasad (Roggero 2011).

To poczucie kryzysu przenika hasło „Student jako wytwórca”. Nazwa projektu została oparta na tytule wykładu wygłoszonego przez Waltera Benjamina dla Towarzystwa Antyfaszystowskiego w Paryżu w kwietniu 1934 roku: „Twórca jako wytwórca”. Wykład ten dotyczył przede wszystkim kwestii, w jaki sposób radykalni intelektualiści mogą interweniować w momentach społecznego kryzysu i jaką postać powinny przyjmować tego rodzaju interwencje. Został zainspirowany przez rosyjskich konstruktywistów i ich tezę, że intelektualista znajduje się w centrum projektu wytwarzania nowego, eksperymentalnego społeczeństwa. Benjamin przejął od konstruktywistów ideę, że produkcja nie sprowadza się do wytwarzania gotowych produktów, ale powinna zawierać w sobie własną rewolucyjną zasadę 
organizującą. Dla Benjamina nie wystarczy, by postępowy/a intelektualist(k)a zadeklarował/a poparcie dla rewolucyjnej transformacji społeczeństwa; jej bądź jego praca powinna odzwierciedlać możliwe sposoby przekształcenia stosunków panujących w kapitalistycznym społeczeństwie. Przekształcenie to powinno być obecne w sposobie, w jaki postępowa praktyka polityczna zostaje ujęta przez samo dzieło, a zwłaszcza w sposobie jego wytwarzania.

Benjamin zwraca się ku teatrowi epickiemu Bertolta Brechta, chcąc zilustrować ten efekt. Teatr epicki zmierza do wywołania u publiczności postawy aktywnej i krytycznej, by odrzeć przedstawienie z iluzji i sztuczności (Wolin 1982), poprzez eksperymentowanie podważając odtwarzanie się iluzji. Sztuka nabiera w ten sposób charakteru pedagogicznego; jej „dydaktyczna” perspektywa każe konsumentom tego produktu nawiązać kontakt z procesem jej produkcji, przekształcając czytelników i widzów we współpracowników (Benjamin 2011). Benjamin rozszerza to podejście na zagadnienie doświadczenia studenckiego i produktywności. W tekście „Das Leben der Studenten”, napisanym w latach 1914/1915, skupił się on na naturze życia studenckiego w kontekście polityki produkcji. Dla Benjamina życie studenckie jest ograniczone poprzez naukę mającą na celu zdobycie zawodu, która zniszczyła twórczego ducha i „całkowicie przejęła uniwersytety i oddzieliła je od nieoficjalnego twórczego życia umysłu” (Benjamin 1996). Sytuacje tę pogorszyło jeszcze odejście od XIX-wiecznej liberalnej humanistycznej wizji kształcenia uniwersyteckiego:

\footnotetext{
Uniwersytet nie jest już zorganizowany z myślą o produktywności studentów, jak wyobrażali to sobie jego założyciele. Uznawali oni studentów jednocześnie za nauczycieli i uczniów; nauczycieli, ponieważ produktywność zakłada całkowita samodzielność, skupienie myśli na nauce, nie zaś na osobowości wykładowcy (Benjamin 1996).
}

Benjamin jest istotny z powodu sposobu, w jaki przedstawia wizję rewolucyjnej pedagogiki opartej na reorganizacji pracy umysłowej. Sugeruje, że pracę tę można zradykalizować poprzez włączenie studenta w proces nauczania i uczenia się jako podmiot, nie jako przedmiot: student ma być producentem, nie zaś konsumentem. Aby rozwinąć jego perspektywę, należy podjąć próbę ożywienia rewolucyjnej pedagogiki we współczesnym kontekście. Temu właśnie poświęcony jest projekt Student jako wytwórca, realizowany na Uniwersytecie w Lincoln.

\section{Student jako wytwórca na Uniwersytecie w Lincoln: akademicka etyka i wartości}

Choć pojęcie studenta jako wytwórcy wywodzi się z XX-wiecznego awangardowego marksizmu, niewielu wykładowców Uniwersytetu w Lincoln jest rewolucyjnymi marksistami. Projekt tworzy warunki dla debat i dyskusji dotyczących polityki i strategii nauczania i uczenia 
się na całym uniwersytecie, opartych na radykalnym słowniku politycznym. To niemałe osiagnięcie, jeśli unaocznimy sobie, do jakiego stopnia dyskurs dotyczący szkolnictwa wyższego został opanowany przez język zarządzania.

Wywrotowy aspekt projektu nie jest tylko skutkiem marksistowskiej teorii społecznej; jest on definicyjna cechą etyki życia akademickiego i eksperymentalnej nauki, na której się ono wspiera. Tych wartości i etyki nie trzeba wynajdywać na nowo; wypływają one z działań pracowników uniwersyteckich z Lincoln i innych miejsc: współtwórców „podwspólności”, spośród których wielu nie porzuciło jeszcze kategorii rewolucji:

\begin{abstract}
Społeczności rozbitków, nauczyciele pisania esejów, doktoranci bez opiekunów naukowych, adiunktki historii marksizmu, wyautowani lub queerowi profesorowie i profesorki zarządzania, instytuty etnologii na publicznych uczelniach, zamknięte kierunki filmowe, jemeńscy redaktorzy studenckich czasopism z wygasłymi wizami, socjologowie $z$ dawniej czarnych uczelni czy feministyczne inżynierki. I co o nich powie uniwersytet? Powie, że są nieprofesjonalni. To nie jest arbitralny zarzut. To jest zarzut przeciwko tym, którzy przekraczają swoja profesję. W jaki sposób ci, którzy i które to robia, przekraczają i przez to uciekaja; w jaki sposób ci rozbitkowie problematyzuja siebie samych, problematyzują uniwersytet, zmuszaja uniwersytet do uznania ich za problem, za zagrożenie? (...) Podwspólność, jej rozbitkowie, sa zawsze w stanie wojny, zawsze w ukryciu (Harney i Moten 2011).
\end{abstract}

Bunt zaczyna się od negatywnej krytyki szkolnictwa wyższego, zwracającej uwagę na złą realizacje jego głównych zadań, dydaktyki i prac badawczych, z powodu której różny priorytet i status przyznawany różnym dziedzinom wprowadza podziały w obręb instytucji i stawia wykładowców i studentów po przeciwnych stronach barykady (Boyer 1990; Brew 2006). Ta negatywna krytyka stanowi podstawę przywiąania projektu Student jako wytwórca do idei nauczania poprzez zaangażowanie w badania (Jenkins i Haley 2009): przeorganizowania związku między nauczaniem i badaniami tak, by studenci stali się częścią projektów badawczych uniwersytetu. Tak właśnie wygląda działanie wywrotowe wykorzystujące język i procedury menedżerskiego uniwersytetu przeciwko niemu. Dla przykładu, projekt redefiniuje zatrudnialność w odniesieniu do świata pracy, co pozwala na zaangażowanie się pracowników naukowych w krytyczną dyskusję na temat bezrobocia wśród studentów i absolwentów, ubóstwa oraz długu (Neary 2006). Z kolei dyskusja na temat środowiska nauki oferowanego studentom prowadzona jest w kategoriach polityki przestrzeni i przestrzenności, tworzenia demokratycznych, „poziomych” przestrzeni, w których współpraca może przybierać na sile (Neary i Saunders 2010). Technologie edukacyjne stosowane na Uniwersytecie w Lincoln nasycone są „etyka hakerską” (Himanen 2001; Winn 2012), w myśl której „nowe podmiotowości zyskują kształt dzięki podejmowanej dobrowolnie, wspólnej pracy” (Soderburg 2008, 2), zwracającej się przeciwko „nudzie utowarowionej pracy” (Soderburg 2008, 44) 
i ,instynktownej reakcji oporu w obliczu regularyzacji i intensyfikacji pracy” (Soderburg 2008, 18). Aktywność hakerska staje się tu praktyka prowokacyjnej emancypacji (Soderburg 2008, 94), w której „walkę toczy się na terenie wroga, dlatego musi ona być w swym charakterze raczej wewnętrznie wywrotowa niż konfrontacyjna" (Soderburg 2008, 134).

Studenci i studentki mogą angażować się w projekt Studentjako wytwórca w sposób, jaki im odpowiada: moga wykorzystać go jako punkt w $\mathrm{CV}$, pozwalający im zdobyć przewagę na rynku pracy (Student as Producer 2011), jako przestrzeń pozwalającą im zyskać wpływ na politykę szkolnictwa wyższego na poziomie krajowym i międzynarodowym (QAA 2012b), albo jako radykalną krytykę umożliwiająca rozwinięcie alternatywnych, eksperymentalnych form wyższej edukacji (Alternative Art College 2012). Choć nie wszyscy studenci cenią sobie oferowaną wolność, projekt może osiagnąć największy dynamizm i skuteczność, jeśli zaangażowani wykładowcy będa pracować na tym oporze, by (w niektórych przypadkach) stworzyć wzbogacone, „kłączowate” środowisko nauki (Coley, Lockwood i O’Meara 2012).

To wywrotowe etyczne i naukowe podejście wpisane jest w biurokratyczne ramy rządzące wykładaniem i uczeniem się na Uniwersytecie w Lincoln - za sprawą swojej strategii nauczania i uczenia się, jak również za sprawą dokumentacji dla wykładowców i studentów, określającej procedury kontroli jakości, nadzór i procedury sprawozdawcze; w jej skład wchodzi podręcznik użytkownika projektu Student jako wytwórca (Student as Producer 2010).

Rodzi się więc problem, jak zachować wywrotowość w kontekście obowiązującego w obrębie szkolnictwa wyższego instytucjonalnego przymusu traktowania studenta jako konsumenta. Rozwiązanie polega częściowo na nieustannej radykalizacji praktyki i zasad projektu, by uniknąć zawłaszczenia; zakłada to krytyczny kontakt z rewolucyjnymi ideami takimi jak instytucja dobra wspólnego Roggero.

\section{Student jako wytwórca: instytucja dobra wspólnego}

Student jako wytwórca istnieje poza Uniwersytetem w Lincoln, stanowiąc część światowego ruchu aktywizmu akademickiego, obejmującego badaczy i studentów, przeciwstawiającego się narastającej korporatyzacji i prywatyzacji, opłatom i deregulacji szkolnictwa wyższego (Neary 2012). Teoria towarzysząca tym działaniom wygląda jak przejęta prosto od najbardziej wywrotowych autorów XX wieku, Henri Lefebvre’a, Guya Deborda czy Raoula Vaneigema, zaktualizowanych, by mogli wypowiedzieć się na temat najnowszych wydarzeń. Te nowe wywrotowe teksty to między innymi: The Coming Insurrection (2009) autorstwa The Invisible Commitee, Introduction to Civil War (2010) kolektywu Tiqqun czy „Communiques from Occupied California: After the Fall is Now" (2010).

Szczególnie ważna książka, która pojawiła się w tym momencie, to The Production of Living Knowledge: The Crisis of the University and the Transformation of Labor in Europe and North 
America Gigiego Roggero (2011). Roggero jest jednym z założycieli kolektywu Edu-factory, zakładającego, że:

(...) tym, czym była fabryka, dziś jest uniwersytet. Niegdyś fabryka stanowiła paradygmatyczne miejsce walki pomiędzy robotnikami a kapitalistami, dziś jednak to uniwersytet jest istotną przestrzenią konfliktu, w którym stawką są status własności wiedzy, reprodukcja siły roboczej oraz tworzenie społecznych i kulturowych hierarchii. Oznacza to, że uniwersytet nie jest kolejną instytucją poddaną suwerennej i rządowej kontroli, a raczej pierwszoplanowym polem wygranych lub przegranych szerszych starć społecznych (Federici i Caffentzis 2011, 152).

Książka pisana jest w perspektywy marksizmu autonomistycznego i studiów postkolonialnych; wykorzystuje teorię marksistowską i poststrukturalistyczną, by odzyskać pojęcie „żywej pracy” jako najważniejszą kategorię marksistowską (Read 2003). Pojęcie to charakteryzuje klasę robotniczą w jej różnorodnym składzie (np. Black Power, ruchy studenckie i kobiece) jako autonomiczny podmiot w obrębie kapitału i siłę, wskutek aktywności której kapitał jest zmuszony przekształcać swoje reżimy akumulacji, kiedy stają się nieskuteczne. W okresie powojennym reżimy te obejmowały keynesizm, monetaryzm, a obecnie neoliberalizm, rozumiany jako szereg zgubnych idei i programów działania (Clarke 1988).

Dla Roggero, podobnie jak dla Druckera, główną kwestią jest wzrost znaczenia wiedzy, co określa on jako „kapitalizm kognitywny”, i rola „pracownika wiedzy”, co razem składa się na nowy reżim produkcji, mający ożywić na nowo akumulację kapitału. Podczas gdy Drucker wskazuje na nieuniknioność znaczenia produkcji opartej na wiedzy w kapitalizmie i związaną z tym śmierć marksizmu, Roggero twierdzi, że uniwersytet i produkcja wiedzy stały się polem walki o to, co nazywa produkcja ,,wiedzy abstrakcyjnej”: wiedzy wytwarzanej na rzecz kapitalistycznego rynku i zgodnej z logika prawa wartości (Roggero 2011, 6), w przeciwieństwie do wytwarzania żywej wiedzy.

Kluczowa dla argumentacji Roggero jest forma instytucjonalna, w której wytwarza się żywą wiedzę: instytucja dobra wspólnego. Jak już wspominałem, istotne dla jego ujęcia jest rozróżnienie między „dobrami wspólnymi” a „dobrem wspólnym”: te pierwsze charakteryzowane są jako „coś, co występuje w naturze (woda, ziemia, środowisko, terytorium, ale także informacja i wiedza)"; drugie jest zdenaturalizowane, tzn. stanowi efekt procesu historycznego i społecznego - kryzysu kapitalizmu, dzięki któremu pewne rzeczy, w tym wiedza, są wspólne, ponieważ „są ucieleśnione w żywej pracy, jej produkcji i jej walkach” (Roggero 2011, 8). Innymi słowy, „dobro wspólne to organizacja czegoś, co przedtem nie istniało, czy też nowy skład istniejących elementów dokonany przez wywrotowa relację społeczną” (Roggero 2011, 8). Żywa wiedza jest dla Roggero czymś, co konstytuuje się w walce klas, współpracy i praktyce radykalnej. Celem jest przekształcenie kryzysu uniwersytetu 
w przestrzeń radykalnych praktyk badawczych, by badać i wytwarzać żywą wiedzę: instytucję dobra wspólnego (Roggero 2011, 29).

Roggero przedstawia też metodę działania towarzysząca temu wywodowi teoretycznemu. Określają ją jako „samokształcenie”, „badanie zaangażowane” lub „współbadanie”: conricerca. Metoda ta jest zakorzeniona w metodach socjologii anarchistycznej i „nowej antropologii” (Roggero 2011, 140), opierającej się na etnografii i etnometodologii: „Współbadanie kwestionuje granice między nauką i polityka, wiedzą i konfliktem, uniwersytetem i kontekstem społecznym, pracą i aktywizmem” (Roggero 2011, 5). Metody tej nie należy mylić z „badaniami robotniczymi”: wiedzą gromadzoną przez socjologów, a następnie przekazywaną robotnikom, by mogli przezwyciężyć fałszywą świadomość i dokonać postępów w walce (Wrigth 2002). Conricerca jest metodą dogłębnie konstytutywną, wktórej „produkcja wiedzy jest bezpośrednio produkcją podmiotowości i konstrukcja organizacji” (Roggero 2011, 138), łączącą działanie intelektualne i polityczne we wspólnym horyzoncie żywej wiedzy jako formy praktyki rewolucyjnej.

Siła książki Roggero polega na zaproponowaniu inspirującego, wyrafinowanego teoretycznie studium przypadku przydatnego dla robotników i studentów protestujących przeciwko polityce zaciskania pasa i prekarności w szkolnictwie wyższym. Jej ograniczenia moga jednak odwrócić uwagę i podważyć rewolucyjne tezy, które głosi.

Jak na metodę mającą na celu denaturalizację dobra wspólnego, główny czynnik sprawczy, żywa praca, robi wrażenie gotowego produktu. Praca nie jest jednak zawsze już istniejaccym, autonomicznym podmiotem; została raczej wytworzona przez stosunki społeczne należące do produkcji kapitalistycznej. Praca jako taka nie istnieje, ale jest konstytuowana jedynie jako abstrakcja rzeczywista (Dienerstein i Neary 2002). O skutkach tej fetyszyzacji pracy mówili wcześniej już inni: na jednym krańcu spektrum uprzywilejowanie pracy jako podmiotu afirmacji prowadzi do roztaczania wizji społeczeństwa, w którym dominuje skupienie na pracy jako realizacji człowieczeństwa; na drugim - uprzywilejowanie pracy prowadzi do niedoceniania skali, w jakiej człowieczeństwo zostało podporządkowane kapitałowi (Postone 1996; Endnotes 2010). Pełna charakterystyka pracy w kapitalizmie, jak również możliwych alternatyw dla niej, wymaga zgłębienia rzeczywistej natury pracy i jej stosunku do świata przyrody (Foster 2000).

Oddzielenie sfery przyrodniczej od społecznej stanowi charakterystyczną cechę XXwiecznego marksizmu (Foster 2000; Burkett 1999; Smith 1990). W autonomistycznej wizji Roggero marksizm mieści się w ekonomii politycznej świata społeczno-ludzkiego, nie zaś w „ekologii politycznej” (Castree 2007; Gorz 1987) czy té̇ „mocnym materializmie historycznym” (Foster 2000, 9). Zaleta „mocnego materializmu historycznego polega na tym, że nie zubaża on stanowiska materialistycznego, usuwając w cień przyrodniczo-fizyczne aspekty bytowania" (Foster 2000, 168). Prawdziwa siła nauki marksistowskiej bierze się 
z ożywienia kategorii natury jako znaczącego wkładu w wartość: „praca jest ojcem bogactwa, ziemia jego matką" (Marks, za: Foster 2000, 168). Jak stwierdza Marks w swojej rozprawie doktorskiej poświęconej epikurejskiemu materializmowi, ,z niczego nic nie uzyskasz” (Foster 2000, 176); zadaniem komunistycznej nauki jest dotarcie do substancji, z której wszystko powstaje, by następnie przekształcać ja tak, by służyła życiu. Podobnie postępuja nauki przyrodnicze, w których aby pielęgnować i ulepszać świat przyrody, konieczne jest zrozumienie jego prawdziwej natury. Dlatego w swojej rozprawie doktorskiej Marks pisze: „na poznaniu meteorów opiera się szczęśliwość” (Marks 1966).

Nauka jest dla Marksa związkiem świata przyrodniczego i społecznego, którego rozwój stanowi historia naturalna (Foster 2000). Marks twierdził jasno, że tylko kiedy „nauka wychodzi od natury, jest prawdziwa nauką" (Foster 2000, 77), dlatego ludzkie dzieje sa „rzeczywistą częścią historii naturalnej (...) Z czasem nauki przyrodnicze obejmą całość nauk humanistycznych i społecznych, a nauki humanistyczne i społeczne obejma całość nauk przyrodniczych: będzie istniała tylko jedna nauka” (Marks, za: Foster 2000, 77). Ta jedna nauka, czyli komunizm, nie będzie korzystać z rozwiązań spekulatywnych czy filozoficznych, ale z naukowej metody badania i rozumowania, opartej na świadomości historycznego postępu ludzkości rozumianego jako alienacja od natury (Foster 2000, 114). Alienacje tę może przezwyciężyć jedynie „działalnoś[ć] »rewolucyjna«, »praktyczno-krytyczna[a]«” (Marks 1949, 5).

Konsekwencją alienacji ludzkości od Ziemi jest obecny kryzys dotykający ludzkość, nękana apokaliptycznymi wizjami katastrofy ekologicznej. Można jej uniknąć tylko za pomoca scalenia tego, co Marks określa jako „metaboliczne pęknięcie” między ludzkością i Ziemią (Foster 2000,114), wywołane przez logikę produkcji kapitalistycznej. Przywrócenie właściwego metabolizmu, przekroczenie granic wyalienowanego życia wymaga nie tylko etnografii, ale i radykalnej etnoekologii, zakorzenionej w metabolicznej relacji człowieka z przyroda (Foster 2000, 221). Proces ten został już zapoczątkowany dzięki odzyskiwaniu „tradycyjnej wiedzy na temat środowiska" posiadanej prze wymarłe lub zagrożone kultury (Foster 2000, 220), tworzeniu „ożywionych uniwersytetów” (Teamey 2012), miejskim gospodarstwom rolnym powstającym w Detroit i innych amerykańskich miastach zniszczonych przez proces dezindustrializacji (Choo 2011), jak również racjonalnemu, biurokratycznemu przewartościowaniu sił nowoczesnej nauki i technologii w obrębie etyki i ram działania, dla których ludzkość i natura stanowią raczej projekty, a nie zasoby.

Zgodnie z najbardziej dychotomiczna interpretacja pojęcia „żywej wiedzy” odróżnienie przez Roggero naturalnych „dóbr wspólnych” od historycznego, społecznego „dobra wspólnego” odtwarza charakterystyczny dla burżuazyjnej nauki rozłam między światem przyrodniczym i społecznym. Rozłam ten odzwierciedla obowiązujący na uniwersytetach podział na nauki przyrodnicze i społeczne, podzielne następnie na dyscypliny. Głównym problemem rozpatrywanym przez projekt Student jako wytwórca jest sposób powiązania nauk 
przyrodniczych i społecznych tak, by stworzyły program dla praktycznej działalności rewolucyjnej.

\section{Studia doktoranckie na uniwersytecie w Lincoln: odnowienie zasad nauki rewolucyjnej; ,jedna nauka”}

Uniwersytet $\mathrm{w}$ Lincoln zrobił jeden mały krok w stronę powiązania nauk przyrodniczych i społecznych za sprawą kierunku studiów doktoranckich „Edukacja badawcza”. Program dostarcza doktorantom wyjątkowej okazji dołączenia do wspólnoty badaczy, odsłaniając przed nimi istnienie szerokiego spektrum metodologii i praktycznych strategii, owocując docenieniem przez nich różnorodności w obrębie uniwersytetu i stwarzając dla nich niekrępujące środowisko umożliwiające zdobywanie kontaktów i rozwój osobisty. W trakcie studiów wprowadzona zostaje wielość perspektyw badawczych i konkretnych metod; jednocześnie rozpatruje się kwestie takie jak krytyczność, etyka i rozpowszechnianie wyników badań. Choć za realizację tego kierunku nie otrzymuje się punktów, nowych doktorantów zachęca się do udziału, by mogli zapoznać się z innymi badaczami w atmosferze sprzyjającej uczeniu się od siebie nawzajem. Realizowane w obrębie kierunku tematy to między innymi: filozofia praktyki badawczej, paradygmaty epistemologiczne, refleksyjność i krytyczność, planowanie badań, jakościowe i ilościowe metody badawcze i etyka badań naukowych. Wycieczki po mieście Lincoln pozwalaja na dokonanie powiązania między naukami przyrodniczymi poprzez skupienie na kulturalnych i naukowych dziejach Lincolnshire; obejmują one też wizyty w Centrum Badawczym Tennysona w gmachu Biblioteki Głównej Lincoln i Konserwatorium Josepha Banksa.

Kierunek „Edukacja badawcza” został opracowany jako interdyscyplinarny zestaw narzędzi dla studentów dowolnego kierunku z Uniwersytetu w Lincoln. Jednak problem, który pojawił się w trakcie jego realizacji, kazał zakwestionować samo pojęcie interdyscyplinarności: okazało się, że istotne jest nie to, jak połączyć ze sobą odrębne i niezgodne dziedziny nauki, ale to, jaka jest prawdziwa natura nauki eksperymentalnej. Zagadnienie formułowane jest poprzez odniesienie do dzieła Roberta Grosseteste'a (1175-1253), biskupa Lincoln i wicerektora Uniwersytetu w Oxfordzie, powiązane z odniesieniem do dzieła innego badaczaeksperymetalisty, Karola Marksa (1818-1883). Wkład Marksa w rewolucyjne nauki społeczne jest dobrze znany za sprawa sławy jego odkryć w dziedzinie ekonomii politycznej. Robert Grosseteste, mniej znany, postrzegany jest przez historyków średniowiecza jako jedna z głównych postaci odpowiedzialnych za rozwój metody nauki eksperymentalnej dzięki jej praktycznemu stosowaniu, a także dzięki odegraniu ważnej roli w stworzeniu nowoczesnego uniwersytetu (Southern 1992; McEvoy 2000). 
Bardzo interesującą i rzadko omawianą kwestią dotyczącą Marksa jest sposób, w jaki opierał się on na dziele antycznych uczonych, zwłaszcza Arystotelesa, opracowując swoja metodę naukowa (McCarthu 1992). Robert Grosseteste jest z kolei znany historykom średniowiecza ze znaczenia, jakie przypisywał w swojej pracy Arystotelesowi. To wspólne nawiązanie do Arystotelesa pozwala powiązać metodę Marksa z metodą Grosseteste’a.

Główną cechą eksperymentalnej metody Grosseteste’a była jego niechęć do scholastyki, nakazującej kierowanie się istniejącym kanonem wiedzy, podobnie jak zachodnie chrześcijaństwo dążyło do narzucenia swojej jurysdykcji poprzez obowiązująca postać doktryny i prawo kanoniczne. Antyscholastycyzm Grosseteste'a zakorzeniony był w stosowaniu wiedzy praktycznej i metodzie, dzięki której można było tę wiedzę zdobyć. Metoda ta, rozwijana za Arystotelesem, polegała na korzystaniu z obserwacji i indukcji, by dostrzegać rzeczywistą istotę zjawisk w odpowiedzi na praktyczne wyzwania, powiązanym z dedukcyjnymi mocami metafizyki: wyobraźnią i intuicją (McEvoy 2000). Ważnym składnikiem teorii naukowej Grosseteste’a było jego ujęcie metafizyki światła, zgodnie z którym światło jest istota wszystkich rzeczy materialnych: „Pierwszą formą cielesna, nazywana przez niektórych cielesnością, jest moim zdaniem światło" (Grosseteste, De Luce, za: McEvoy 2000). Światło jest dla niego istota materii, tworzaca na drodze rozciagania i kondensacji formy składające się na wszechświat: przeczucie teorii wielkiego wybuchu (McEvoy 2000). Sformułowanie tej teorii miało charakter w dużej mierze teologiczny, ponieważ Grosseteste wsparł ją argumentem, że Bóg jest tożsamy ze światłem i istotą wszystkiego. Podobnie wiedza zostaje nam udzielona na drodze boskiej iluminacji i stanowi istotę „odbicia” Boga. Wielkość wizji Grosseteste’a materializuje się do dziś w architekturze katedry w Lincoln (Hendrix 2011). Jego pisma „,stanowią początek nowożytnej nauki” (Hendrix 2011, 4), nie dlatego, że „stoją na ramionach olbrzymów”, ale dlatego, że wywarły zakłócający, wywrotowy wpływ:

\footnotetext{
(...) otworzyły one nieograniczone możliwości nowej wiedzy, niezależnej od tego, co napisali uczeni wcześniej, a sprawdzanej za pomocą dalszych obserwacji, spośród których większość należy do przyszłości (...) wiedza ta nie prowadzi do ładu i ujednolicenia, ale do zmiany i zamieszania (Southern 1992, 36-37).
}

To właśnie wywrotowość cechująca eksperymenty Grosseteste’a decyduje o kształcie jego przedsięwzięcia naukowego i potwierdza coś, co wiemy i czego zarazem nie wiemy: że nauka jest ze swej istoty działalnością rewolucyjna. 


\section{Główne aspekty metody naukowej Marksa}

Marks podąża za Grosseteste’em, przywiązując wagę do Arystotelesowskiej metody indukcyjno-dedukcyjnej: należy dotrzeć do istoty (wewnętrznego powiązania) materii na drodze obserwacji/doświadczeń i rozumowania. Główną cechą Marksowskiej nauki doświadczalnej, wypływająca z metody Arystotelesowskiej, jest niechęć do dogmatycznych założeń, obecnych zarówno w scholastyce, jak i w liberalnych naukach społecznych. Nauki te - ekonomia, filozofia, socjologia - odmawiają istnienia jakiejkolwiek zasadzie jednoczącej świat społeczny. Dla nauk liberalnych społeczeństwo składa się z chaotycznej i złożonej sieci stosunków wymiany i konsumpcji, odzwierciedlając ideologię leżącą u podłoża modeli rozwoju społecznego opartych na kategorii rynku, wedle których wartość towaru określana jest w procesie wymiany (Clarke 1991).

Dzięki swojej metodzie indukcyjnej Marks ukazuje, że istotą bogactwa społecznego nie jest nagromadzenie rzeczy, którym wartość nadaje rynek, ale praca abstrakcyjna, czyli wartość: zakrzepła ludzka energia, zmaterializowana w postaci towarów, które następnie podlegają wymianie. Marks określa te towary mianem „rzeczywistych abstrakcji” - tzn. społecznym (niematerialnymi) procesami ukrytymi za materialną formą. Choć wartość towarów rozpoznawana jest w procesie wymiany, rozszerzony aspekt wartości (wartość dodatkowa) wytwarzana jest w procesie produkcji za sprawą wyzysku ludzkiej pracy i świata przyrody. Podobnie jak Grosseteste, Marks wiąże ze sobą metodę indukcyjną i dedukcyjna; podczas gdy Grosseteste uznawał Boga za istotę wszystkich rzeczy, Marks odkrył logikę rozszerzania się wartości pod pojęciem kapitału. Wykorzystując moc rozumu, w oparciu o swój projekt krytyki ekonomii politycznej, Marks zastąpił mistyczną metafizykę, taką jak ta obecna w teorii światła/Boga Grosseteste’a, kapitałem jako „automatycznym podmiotem” (jak mówi w Kapitale) ludzkiego społeczeństwa, formą „podmiotowości pozbawionej ego czy świadomości” i substancję „uniwersum społecznego” (Postone 1996): „nadrzędną formę społecznego istnienia" (Clarke 1988). Można też prześledzić dalsze powiązania między polityczną kosmologia Marksa i rewolucyjną nauką Einsteina (Neary 2004; Neary i Rikowski 2002; Kay i Mott 1982).

Teoria społeczna Marksa, podobnie jak nauka doświadczalna Grosseteste’a, ma charakter zakłócający i wywrotowy, stanowiąc nie tyle ramy dla działania, ile krytyczną perspektywę, ukazującą nam ludzkie potrzeby i zdolności jako prawdziwą substancję uspołecznienia, a poprzez utwierdzenie tych potrzeb i zdolności także możliwość społeczeństwa dostatku (Kay i Mott 1982). Wielkość komunistycznej nauki Marksa polega na ukazaniu, że przekształcenie społeczeństwa kapitalistycznego jest nieodłączne od walki wychodzącej od niemożliwości życia w tym społeczeństwie”. „Historia wszystkich dotychczasowych społeczeństw jest historią walk klasowych” (Marks i Engels 1962, 514). 
Najważniejsze odkrycie Marksa głosi, że kryzys kapitału jest tożsamy z utwierdzeniem się sił ludzkości i odnową świata przyrody.

Dla Marksa komunistyczna nauka jest nauką rewolucyjną - podobnie pojmował naukę Grosseteste: nauka ma być podstawową formą zakłócającej transformacji. Dla Marksa zakłócenie to zachodzi raczej na poziomie społeczeństwa niż świata idealnego. W dzisiejszym świecie, w którym kapitał zastapił Boga jako „najwyższa forma bytu” (Clarke 1988), musimy zadać sobie pytanie, do jakiego stopnia zakłócenie to jest zacierane przez nierewolucyjną naukę, tzn. akademicki kapitalizm. By odnowić ducha nauki rewolucyjnej, należy zakorzenić myśl Grosseteste’a w świecie społecznym i materialnym oraz „sprowadzić go na ziemię”. Oznacza to uznanie jego metafizyki światła/Boga za abstrakcję idealną, a następnie przekształcenie jej w formę, w której Marks ukazał działanie abstrakcji - abstrakcję rzeczywista, istotę uniwersum społecznego, stworzoną z ludzkich energii/zdolności (pracy abstrakcyjnej) i zestalonej w postaci towarów. W ten sposób możliwe będzie odkrycie sposobów na odblokowanie wybuchowej ludzkiej i przyrodniczej energii zamkniętej w owych abstrakcjach rzeczywistych (formie towarowej), by móc zaspokajać i rozwijać nowe rzeczywiste ludzkie potrzeby i zdolności w sposób nieszkodliwy dla świata przyrody, z którego wywodzi się życie.

\section{Pytanie badawcze}

Głównym zagadnieniem zasługującym na rozpatrzenie przez studentów i naukowców jest stopień, w jakim nauka rewolucyjna jest ograniczana przez przedsięwzięcia naukowe ukierunkowane nie na rozwój wiedzy, ale na rozwój kapitalizmu akademickiego (naukę nierewolucyjna). Aby odkryć na nowo ducha komunistycznej nauki rewolucyjnej, należy wprowadzić ideał uniwersytetu kierującego się zasadami nauki rewolucyjnej. Jak uformować ideę uniwersytetu, by wspierała ona i pozwalała rozwijać tę wizję nauki rewolucyjnej? Oto główne zadanie i cel projektu Student jako wytwórca.

Przetożyla Joanna Bednarek 


\section{Wykaz literatury}

Alternative Art College. 2012. http://alternativeartcollege.co.uk/ (data dostępu: 24.08.2015).

Augé, Marc. 2013. Nie-miejsca: Wprowadzenie do antropologii hipernowoczesności. Tłum. Roman Chymkowski. Warszawa: PWN.

Benjamin, Walter. 2011. „Twórca jako wytwórca.” W tegoż, Twórca jako wytwórca: Eseje i rozprany. Tłum. Robert Reszke. Warszawa: KR.

Benjamin, Walter. 1996. „The Life of Students.” W Selected writings, t. 1, 1926-1936, red. M. Bullock, M.W. Jennings. Cambridge: Belknap Press of Harvard University Press.

Birnbaum, Robert. 2000. Management Fads in Higher Education: Where They Come From. What They Do. Why They Fail. San Francisco: Jossey-Bass.

Bovill, Catherine, Cook-Sather, Alison i Peter Felten. 2011. „Students as Co-creators of Teaching Approaches, Course Design, and Curricula: Implications for Academic Developers." International Journal for Academic Development 16(2).

Boyer, Ernest. 1990. Scholarship Reconsidered: Priorities of the Professoriate. Princeton, New Jersey: Carnegie Foundation for the Advancement of Teaching.

Brew, Angela. 2006. Research and Teaching: Beyond the Divide. London: Palgrave Macmillan.

Browne, Lord. 2010. „Independent Review of Higher Education Funding and Student Finance.” http://webarchive.nationalarchives.gov.uk/+/hereview.independent.gov.uk/hereview/ (data dostępu: 24.08.2015).

Burkett, Paul. 1999. Marx and Nature: A Red and Green Perspective. New York: St Martin's Press.

Castree, Noel. 2007. „Making First World Political Ecology.” Environment and Planning A 39(8).

Choo, Kristin. 2011. „Plowing Over: Can Urban Farming Save Detroit and Other Declining Cities? Will the Law Allow It?" ABA Journal. www.abajournal.com/magazine/article/plowing_over_can_urban_farming_save_detroi t_and_other_declining_cities_will/(data dostępu: 24.08.2015).

Clarke, Simon. 1988. Keynesianism, Monetarism and the Crisis of the State. Aylesbury: Edward Elgar.

Clarke, Simon. 1991. Marx, Marginalism and Modern Sociology. London: Palgrave Macmillan.

Coley, Rob, Lockwood, Dean i Adam O’Meara. 2012. „Deleuze and Guattari and Photography Education". Rhizome 23. http://rhizomes.net/issue23/coley/index.html (data dostępu: 24.08.2015).

Cote, Mark., Day, Richard. i Greig de Peuter. 2007. Utopian Pedagogy: Radical Experiments Against Neoliberal Globalisation. Toronto: University of Toronto Press.

DeGolyer, Michael.1992. The Greek, Accent of the Marxian Matrix. W Marx and Aristotle, red. G. McCarthy. Maryland: Rowman \& Littlefield.

Dinerstein, Ana. i Micheal Neary (red.). 2002. The Labour Debate: The Theory and Practice of Capitalist Work. London: Ashgate.

Drucker, Peter. 1993. Post-Capitalist Society. New York: Harper Business.

Du Gay, Paul. 2000. In Praise of Bureaucracy: Weber, Organisation, Ethics. Los Angeles-London: Sage. 
Edu-factory Collective. 2009.Towards an Autonomous University. New York: Autonomedia.

Endnotes. 2010. „Communisation and Value Form Theory. \#2.” http://endnotes.org.uk/articles/4 (data dostępu: 24.08.2015).

Federici Silvia. i Caffentzis Geogrge. 2011. Uwagi o Edu-Factory i kapitalizmie kognitymnym. W Edu-factory: Samoorganizacja i opór w fabrykach wiedzy, red. Jan Sowa, Krystian Szadkowski. Kraków: ha!art.

Foster, John Bellamy. 2000. Marx's Ecology: Materialism and Nature. New York: Monthly Review Press.

Fuller, Steve. 2009. The Sociology of Intellectual Life: The Career of the Mind in and around the Academy. Los Angeles-London: Sage.

Goodall, Amanda. 2009. Socrates in the Boardroom: Why Research Universities Should be Led by Top Scholars. Princeton: Princeton University Press.

Gorz, André. 1987. Ecology as Politics. London: Pluto Press.

Harney Stefano i Fred Moten. 2011. „Uniwersytet i podwspólność.” Tłum. Magdalena Prusinowska, Małgorzata Zielińska, Piotr Kowzan. http://www.ha.art.pl/prezentacje/39-edufactory/1815-stefano-harney-fred-motenuniwersytet-i-podwspolno.html (data dostępu: 24.08.2015).

Hagyard, Andy. 2009. „Student Intelligence: Challenging Received Wisdom in Student Surveys." W The Future of Higher Education: Policy, Pedagogy and the Student Experience, red. L. Bell, H. Stevenson i M. Neary. London: Continuum Press.

HEFCE. 2010. „Employability statement.” www.hefce.ac.uk/pubs/year/2010/cl122010/ (data dostępu: 24.08.2015).

Hendrix, John. 2011. Architecture as Cosmology: Lincoln Cathedral and English Gothic Architecture. New York, Oxford: Peter Lang.

Himanen, Pekka. 2001. The hacker Ethic and the Spirit of the Information Age. London: Random House.

Holloway, John. 2010. Change the World Without Taking Power. London: Pluto Press.

Invisible Committee. 2009. The Coming Insurrection. Los Angeles: Semiotexte.

Jenkins, Alan i Mick Healey. 2009. „Developing Undergraduate Research and Inquiry.” York: Higher Education Academy. www.heacademy.ac.uk/assets/York/documents/resources/publications/DevelopingU ndergraduate Final.pdf (data dostępu: 24.08.2015).

Kay, Geoffrey. i James Mott.1982. Political Order and the Law of Labour. London: Macmillan.

Lambert, Cath, Mockridge, Alex, Taylor, Paul i Danny Wilding. 2012. „Reinventing Engagement." W Engaging with Learning in Higher Education, red. I. Solomonides, A. Reid i P. Petocz. Oxford: Libri.

Lampedusa, G. Thomasi di. 1961. Lampart. Tłum. Zofia Ernstowa. Warszawa: PIW.

Lyotard, Jean-François. 1997. Kondycja ponowoczesna: Raport o stanie wiedzy. Tłum. Małgorzata Kowalska i Jacek Migasiński. Warszawa: KR.

Marks, Karol. 1949. Tezy o Feuerbachu. W Karol Marks, Fryderyk Engels, Dqieła wybrane, t. 2. Warszawa: Książka i Wiedza. 
Marks, Karol. 1961. Ideologia niemiecka, MED, t. 3. Warszawa: Książka i Wiedza.

Marks Karol, Engels Fryderyk. 1962. Manifest Komunistyczny. W MED, t. 4. Warszawa: Książka i Wiedza.

Marks, Karol. 1968. Kapitał, t. I. W MED, t. 23. Warszawa: Książka i Wiedza.

Marks, Karol. 1972. Krytyka programu gotajskiego. W MED, t. 19. Tłum. Antoni Bal, Stefan Bergman. Warszawa: Książka i Wiedza.

Marks, Karol. 1966. Różnica miédzy demokrytejska a epikurejska filozofia prayrody: rozprawa doktorska wraz z aneksem i pracami praygotowawczymi. Tłum. Irena Krońska. Warszawa: Ksiażka i Wiedza.

McEvoy James. 2000. Robert Grosseteste. Oxford: Oxford University Press.

McNally, David. 2011. Global Slump: The Economics and Politics of Crisis and Resistance. Oakland, CA: PM Press.

Neary, Mike. 2004. „Travels in Moishe Postone’s Social Universe: a Contribution to a Critique of Political Cosmology." Historical Materialism 12(3).

Neary, Mike. 2006. „Crime and the University: The Story of Sort'd - a Community Education Project”. Probation Journal. 53(2). http://prb.sagepub.com/content/53/2/124.full.pdf (data dostępu: 24.08.2015).

Neary, Mike., 2012a. „Beyond Teaching in Public: The university as a Form of Social Knowing". W Towards Teaching in Public: Reshaping the Modern University, red. M Neary, H. Stevenson, L. Bell. London: Continuum.

Neary, Mike., 2012b. „Teaching Politically: Policy, Pedagogy and the New European University". Critical Journal of Education Policy (w przygotowaniu).

Neary, Mike i Glenn Rikowski. 2002. „Time and Speed in the Social Universe of Capital”. W Social Conceptions of Time: Structure and Process in Work and Everyday Life, red. G. Crow, S. Heath. Basingstoke: Palgrave Macmillan.

Neary, Mike i Gary Saunders. 2011. „Leadership and Learning Landscapes: The Struggle for the Idea of the University". Higher Education Quarterly. 65(4).

Neary, Mike., Winn, Joss. 2009. „The Student as Producer: Reinventing the Student Experience in Higher Education". W The Future of Higher Education: Policy, Pedagogy and the Student Experience, red. L. Bell, H. Stevenson, M. Neary. London: Continuum.

Peters, Tom.1992. Liberation Management. Basingstoke: Macmillan.

Postone, Moishe. 1996. Time, Labour and Social Domination: a Reinterpretation of Marx's Critical Theory. Cambridge: Cambridge University Press.

QAA. 2012a. „Student Engagement: Students Get to the Heart of the Issues.” www.qaa.ac.uk/Partners/students/student-engagement-QAA/Pages/default.aspx (data dostępu: 24.08.2015).

QAA. 2012b. „QAA partners.” www.qaa.ac.uk/Partners/students/student engagementQAA/Pages/Dan-Derricott.aspx (data dostępu: 24.08.2015).

Read, Jason. 2003. The Micro-Politics of Capital: Marx and the Prehistory of the Present. Albany: State University of New York Press.

Rhodes, Frank. 2001. The Creation of the Future: The Role of the American University. Ithaca, NY: Cornell University Press. 
Roggero, Gigi. 2011. The Production of Living Knowledge: The Crisis of the University and the Transformation of Labour in Europe and North America. Philadelphia: Temple University Press.

Shakespeare, William. 1991. Król Lear. Tłum. Stanisław Barańczak. Poznań: W Drodze.

Slaughter, Leslie i Gary Rhoades. 2004. Academic Capitalism and the New Economy: Markets, State and Higher Education. Philadelphia: Johns Hopkins University Press.

Smith, Neil. 1990. „The Production of Nature.” W Uneven Development: Nature, Capital and the Production of Space. Georgia: University of Georgia Press.

Soderberg, Johan. 2008. Hacking Capitalism: The Free and Open Source Software Movement. London, New York: Routledge.

Southern, Richard W. 1992. Robert Grosseteste: The Growth of an English Mind in Medieval Europe. Oxford: Clarendon Press.

Student as Producer. 2010. http://studentasproducer.lincoln.ac.uk/ (data dostępu: 24.08.2015).

Student as Producer. 2011. Video. http://studentasproducer.lincoln.ac.uk/2011/03/09/ (data dostępu: 24.08.2015).

Taylor, Paul. i Danny Wilding. 2009. „Rethinking the Values of Higher Education: the Student as Collaborator and Producer: Undergraduate Research as a Case Study." www.qaa.ac.uk/Publications/InformationAndGuidance/Documents/Undergraduate.p df (data dostępu: 24.08.2015).

Teamey, Kelly. 2012. „New and Enlivened Universities. Utopian Spaces of Non Hierarchical and Indigenous Affinities: Queries and Possibilities for Research." Prezentacja w trakcie warsztatów Reimaging Universities. Institute of Education. Londyn, 15 lipca 2012.

Tiqqun. 2010. Introduction to Civil War. Los Angeles: Semiotexte.

Weber, Max. 2002. Gospodarka i społeczeństwo. Zarys socjologii rozumiejacej. Tłum. Dorota Lachowska. Warszawa: PWN.

Winn, Joss. 2012. „Hacking the University: Lincoln’s Approach to Openness.” JISC [studium przypadku].

www.jisc.ac.uk/media/documents/topics/openeducation/JISC_LincolnsCaseStudy.pdf data dostępu: 24.08.2015 (data dostępu: 24.08.2015).

Wolin, Richard. 1982. Walter Benjamin: an Aesthetic of Redemption. Columbia: Columbia University Press.

Wright, Steve. 2002. Storming Heaven: Class Composition and the Struggle in Italian Autonomia. London: Pluto Press.

Zandstra, Roos. i Elisabeth Dunne. 2009. „Students as Agents of Change.” http://extra.shu.ac.uk/irconference2009/docs/presentations/Roos_Zandstra_\&_Liz_ Dunne.pdf (data dostępu: 24.08.2015). 
Mike Neary - przed zajęciem stanowiska Dziekana do spraw Dydaktyki na Uniwersytecie w Lincoln w 2007 roku Mike wykładał socjologię polityczną na Uniwersytecie w Warwick w latach 1994-2007. Zanim rozpoczął karierę akademicka, zajmował się młodzieżą i rozwojem lokalnej społeczności w południowym Londynie w latach 1980-1994.

\title{
DANE ADRESOWE:
}

Mike Neary

Dean of Teaching and Learning, Direxctor of the Graduate School and Director of the Centre for Educational research and Development

University of Lincoln

Brayford Pool, Lincoln LN6 7TS

EMAIL: mneary@lincoln.ac.uk

CYTOWANIE: Mike Neary. 2015. „Student jako wytwórca: instytucja dobra wspólnego? Czyli o tym, jak odzyskać komunistyczna/rewolucyjną naukę.” Praktyka Teoretyczna 4 (18): 123144.

DOI: $10.14746 /$ prt.2015.4.5

\section{AUTHOR Mike Neary}

TITLE: Student as producer: an institution of the common? (or how to recover communist/revolutionary science)

\begin{abstract}
This paper presents the further development of the concept of student as producer from a project that seeks to radicalise the idea of the university by connecting research and teaching, to a vision of higher learning and revolutionary science based on the reconnection of the natural and the social sciences. The argument is sustained and developed by a critical engagement with classical texts in management studies as well as Marxist writing that has emerged out of the recent wave of student protests against the increasing privatisation and financialisation of higher education. The paper provides a case study where the natural and the social sciences are being brought together in a postgraduate research education programme at the University of Lincoln. The case study includes a debate about the essence of revolutionary science through an exposition of the work of two major revolutionary scientists, Robert Grosseteste (1170-1253) and Karl Marx (1811-1883).
\end{abstract}

KEYWORDS: bureaucracy, the common, revolution, university, natural science, social science 